\title{
(Re)thinking Teacher Educator Professional Identity
}

\author{
Authors: Dr Penny Amott and Professor Lynn Ang \\ Institution: UCL - Institute of Education, London \\ Email addresses: l.ang@ucl.ac.uk; p.amott@ucl.ac.uk
}

\section{Introduction}

There is a growing body of research in the international literature which problematises notions of teacher educator professional identity, in particular early career teacher educators, that is, those involved in the training of teachers. As individuals transition from teacher to teacher educator, their previous identity as a teacher can become a source of 'credibility' with the students they work with. However, research shows it can also impede their developing identity as a teacher educator.

This chapter will seek to explore the problematic nature of teacher educator identity and examine issues that early career teacher educators face during transition into their new role. It argues for the importance of (re)thinking conceptualisations of professional identity and the ways in which teacher educators can be supported to engage more effectively in professional learning and reflective practice through research and collaboration.

\section{The Changing Context of Teacher Education}

It is important to establish who we mean by a Teacher Educator. This may be defined in broad terms as an education professional working to support the professional learning of teachers, whether that be student teachers, newly qualified teachers or experienced teachers. Many teacher educators are those who started their careers as qualified school teachers in the pre-school, primary, secondary school or post-compulsory phases and then progressed in their profession to become Teacher Educators involved in the professional development other teachers. They may be school-based teacher educators who mentor students and teachers or university-based teacher educators who are employed by a University or Higher Education Institution and responsible for initial teacher preparation. In this entry the focus will be on the latter group of teacher educators, that is, those who teach teachers in universities or higher education settings.

Historically, the work of teacher education has primarily been the domain of Teacher Training Colleges, providing a professional qualification (often not at degree level). The drive for teachers to be qualified at degree level meant that traditional universities started to offer Initial Teacher Education (ITE) ${ }^{1}$ programmes as additional undergraduate degrees. In England, Teacher Training Colleagues were either subsumed as a faculty within a larger university or gained status as a 'new university' within 1992 Higher Education reforms. This led to Teacher Education being perceived as low status within the university sector, which has impacted teacher educators as they seek to be accepted within the 'academy'. In addition, the nature of ITE varies significantly across different national contexts. This may be in relation to the type of degree programmes offered, such as 3-4 year undergraduate degrees, 1 year post-graduate certificate of education (this PGCE is primarily

\footnotetext{
${ }^{1}$ There is an ongoing debate around the use of the terms 'Teacher Education' or 'Teacher Training', with the latter denoting a more instrumentalist view of teacher preparation with a focus on learning practice through apprenticeship. This chapter uses the phrase 'Teacher Education' where the focus is on preparing teachers who have a depth of theoretical and practical understanding about teaching and the ability to critically reflect on this understanding.
} 
what is offered in England), 2-3 year masters programmes (Finland offer this for all teachers). In addition, some countries (particularly with the developing world context) continue to offer certificate or diploma level training in order to meet the national demand for teachers. The level of qualification expected of teacher educators also varies across national contexts, where some countries focus on these teacher educators having school teaching expertise only and others look for teacher educators to have a minimum of a Masters Degree or even requiring qualifications at doctoral level (e.g. Israel). The level of qualification of some teacher educators can also impact on their professional identity, perhaps perceptions of them as less qualified than others within their university context.

Another aspect of ITE that varies across national contexts is the approach to school-based teaching practice within the ITE programme. Some countries offer this within Teacher Training Schools (for example Finland), providing intensive opportunity for clinical practice with student learners. Others integrate it as part of masters' level clinical teaching and research experience (for example Ontario, Canada or various implementations in Australia). The majority offer this through partnerships with mainstream schools and early childhood settings. The proportion of time required in school is also an area of variation. In England, there has been a strong move to school-based training. This means that post-graduate programmes have two-thirds of time within school settings. In addition, England is almost unique in providing employment-based ITE where student teachers are working as unqualified teachers and learning 'on the job'; but this is also a feature of 'Teach for America' and 'Teach First'. Whilst the majority of teacher educators work within Higher Education, a small number of School Based Teacher Educators are the sole providers of ITE for student teachers in these employment-based routes into teaching. For these school-based teacher educators their developing teacher educator identity may be considered more problematic, as they juggle their work as 'teacher of children(pupils)' and as 'teacher of teachers'. These school-based teacher educators are more than 'just teachers' or 'just mentors' and are directly responsible for their student teachers' learning and therefore their developing identity as 'teacher educator' is of paramount importance. In addition, they are often working in isolation within their school context and may lack the support of a 'Community of Practice' of fellow school-based teacher educators or of university-based teacher educators.

Importantly, many countries now have standards for teachers by which they are held accountable and which act as a gateway for student teachers as they take up their first teaching position. However, there are only two countries that have adopted standards for Teacher Educators: The 'Standards for Teacher Educators' by the Association of Teacher Educators in USA; and the VELON 'Standards for Teacher Educators' in the Netherlands. This again may be a reflection of the lack of awareness or understanding around the unique role of a teacher educator.

\section{The problematic nature of Teacher Educator identity}

The development of a Teacher Educator identity requires time and effort in negotiating some complex roles and responsibilities for those who are 'teacher turned scholar and learner'. Many Teacher Educators have moved from teaching in a school or early childhood context into 'teaching teachers' as part of ITE programmes within Higher Education. Whilst these teachers have developed an expertise as a teacher of children (pupils), there is an assumption that this will translate seamlessly into becoming an effective teacher of adults, that is student teachers. This involves moving from being a first order practitioner (teacher of children) to a second order practitioner (teacher of teachers) - an 'expert become novice'. Whilst these novice teacher educators may have strong pedagogical knowledge and skills as school teachers, their experience of Higher Education is likely to be drawn from their own training within ITE and their engagement as mentors of student 
teachers in schools. A teacher educator is expected to engage in 'teaching about teaching' that requires the development of new set of pedagogical knowledge and skill. The work of Boyd and Harris (2010) identifies that for early career teacher educators there is tendency to retain their teacher identity in their striving for credibility with the student teachers, rather than develop an academic identity suitable for their work within Higher Education, which further challenges their developing identity as a teacher educator. Whilst their expertise as a school teacher gains the respect of these student teachers, these early career teacher educators need to gain knowledge of an effective pedagogy for ITE that enables them to support the professional learning of their students. As these novice teacher educators move into ITE, they have to develop expertise as a teacher of teachers and as a scholar and researcher, whilst continuing to build their knowledge of teaching and subject expertise through ongoing professional learning.

Particularly challenging aspects of their role include engaging with research to support professional learning, engaging in academic writing and assessment, and in developing their own researcher endeavours (which is often expected of teacher educators working in Higher Education). The pressure of publishing that is so entrenched in Higher Education is often incongruent with the demands of teaching time, with implications on the developing identity of Teacher Educators as they shift from a role as user of knowledge to producer of research and knowledge. The institutional context exacerbates these challenges as Teacher Educators begin to negotiate shifting expectations, cross disciplinary boundaries and adapt to the structures and relationships within the new communities they operate in. In light of these challenges, there is a growing recognition of the need for induction and early career support for teacher educators as they transition into their role, particularly within the first three years. However, in most national contexts this is still not embedded into teacher educator preparation and teacher educators are mostly assumed to 'learn on the job'.

\section{Defining Teacher Educator Identity}

Due to the complex and shifting nature of Teacher Educator identity a constructivist view of identity is often adopted which sees identity as unstable and constantly changing; that it is constructed within a social context and is therefore shaped by that context and may vary between contexts; and it is a personal interpretation of self which is formulated and shaped for purpose. This is encapsulated by Davey's (2013) definition that '...identity is not a singularity but is better conceived of as overlapping, dynamic, unstable, and relative. It involves multiple 'selves', each continually reconstructed and re-expressed in the various personae and responsibilities take[n] on during our course of work.' (p117). The multiple selves of the teacher educator might be as teacher, teacher in Higher Education, teacher of teachers and as a researcher. Crucial to the development of Teacher Educator identity is the transition from teacher to Teacher Educator, moving from identity as teacher to identity as Teacher Educator or researcher.

A useful concept in considering teacher educator identity is the notion of Identity dissonance adopted by Warin and Muldoon (2009). They suggest three key premises in relation to this concept: firstly, that 'identity is a sense-making devise' which might be illusionary but functions to govern our choices and decision-making; secondly, that an individual constructs a 'narration of self' as a means of organising their self-experiences and integrating their personal and professional selves; and thirdly, that 'identity is activated when dissonance occurs.' (pp. 235-6). As teacher educators transition into the role of a teacher educator this can be supported by opportunities to engage in 'identity work' perhaps through narrative approaches and through working within a Community of Practice working to develop their with the support of other teacher educators. 


\section{Approaches That Support Developing Teacher Educator Identity}

It is crucial to support the transition for new Teacher Educators into their role. Ideally this should entail an effective and substantial induction into the new role. This field of teacher educator professional learning is a relatively new development. Some universities are starting to implement such induction processes and to consider more effective approaches to supporting these new teacher educators into their role. However, the majority still rely on 'informal' approaches and the notion of 'learning on the job'; such as shadowing a colleague and teacher educators' own motivation to engage with research and reading in their field to develop expertise.

An increasing amount of research has considered models of professional development that might support teacher educators, particularly those in their early career stages. The existing literature on teacher educator identity shows four features of induction for new teacher educators: Learning communities - which is in alignment with the concept of a community of practice; Supportive relationships - such as being assigned a more experienced teacher educator as a mentor; Reflective activities - may include opportunities to engage in collaborative narrative practices or more structured opportunities for critical reflection on their developing role, such as self-study; Research may include being users of research or 'research informed' in their practice or producers of research, often working collaboratively with a more experienced teacher educator researcher. Overall the body of research on professional learning for teacher educators clusters around two main areas: using research to support professional learning and collaborative learning supporting reflective practice.

Research in this field highlights the importance of developing researcher identities for new teacher educators, suggesting that this leads to rich professional learning, and that there is a congruence between teacher educator as researcher and as a teacher of teachers. One notable barrier for teacher educators engaging in research is the time available for such work; particularly when working on the very intensive one-year PGCE programmes. Collaborative approaches to research and mentoring for these early career researchers are particularly supportive for nurturing the skills and confidence to adopt a 'researcher identity'. There is a growing body of research by teacher educators using self-study approaches. This form of critical self-reflection has been shown to be supportive for the development of teacher educator identity. (See as an example the work of S-STEP 'Self-Study of Teacher Education Practices' one special interest group of the American Educational Research Association.)

Developing models for collaborative reflective practice has also proven to be effective. This can be activated through establishing a community of practice for early career teacher educators. This might focus on supporting collaborative research and academic writing. Alternatively, the use of narrative practices such as a 'professional life history' approach, providing a discursive space for professional learning. Researchers have also advocated a model of 'praxeological-learning' in the university classroom where Teachers Educators are encouraged to engage in participative, reflective research with their student teachers in real world situations that have a direct influence on the school context or classroom; and in doing so, empower students as well as themselves by undertaking applied research to enhance their own knowledge and learning (Pascal and Bertram, 2012). In addition, when considering approaches to support teacher educators' professional learning and developing identity, it is useful to consider the possible stages of teacher educator development in their role. Ulvik and Lunenberg (2018) suggest three stages: induction, early career and lifelong learning. They suggest that the induction stage during the first year is about 'survival' in terms of understanding the teacher education system in which they work; 'shifting the lens' of expertise to the pedagogical demands of working with adults; and 'laying the foundation' for scholarship and research activity. The early career stage is focused on a teacher educator extending their knowledge 
of the contexts in which they work and developing professional networks; but that there is a demand for continuing professional development in which they are 'working the dialectic' (CochranSmith, 2005, in ibid) between scholarship and practice. Moving into lifelong learning, the teacher educator may focus on responding to developments within society and education, and increasing their support and influence on practice within schools.

\section{Towards a Pedagogy of Initial Teacher Education}

Fundamental to becoming a practitioner within ITE is understanding the nature of the pedagogy of ITE. However, this has proven to be an illusive concept which has only gathered more serious consideration in recent years. This might be considered 'meta-teaching' or 'teaching about teaching'. It requires that teacher educators have what can be categorised into four intersecting areas of knowledge: knowledge of relevant research, knowledge of a pedagogy of higher education, subject and pedagogical knowledge within their specific subject domain and knowledge of current local or government initiatives. As teacher educators lose their sense of credibility as a teacher (and their associated teacher identity) they should be gaining credibility as a teacher educator (and their teacher educator identity) through their growing knowledge and skills as teacher educators. Having a clear understanding of effective pedagogy within ITE and taking a research-informed approach to their developing practice will support this.

\section{Conclusion}

The quality of any education system depends on the preparation of future teachers and how well prepared teacher educators are in supporting teachers to meet the challenges of their role in the classroom or early childhood setting. Indeed, the evidence is clear that teacher educators play a crucial role in shaping the future of the teaching workforce. However, fundamental to the enactment of this role is a secure identity as a teacher educator. This requires a shift in both understanding and practice where the focus moves from teaching children to teaching teachers.

At the core of the Teacher Educator's role is to help teachers respond to the diverse learning needs of children. To improve learning for all, it is therefore important that teachers have the best possible education and those who train teachers must have the required knowledge, skills and experience to prepare teachers adequately and effectively. The expert role of Teacher Educators must be prioritised so that they can adequately prepare and orient teachers in making transformative change for future generations.

\section{References}

Boyd, P., \& Harris, K. (2010). Becoming a university lecturer in teacher education: expert school teachers reconstructing their pedagogy and identity. Professional development in education, 36(1-2), 9-24.

Davey, R. (2013). The professional identity of teacher educators - Career on the cusp? Oxon: Routledge.

Ulvik, M., \& Lunenberg, M. (2018). Stages of Professional Development. Retrieved from https://info-ted.eu/stages-of-professional-development/

Warin, J., \& Muldoon, J. (2009). Wanting to be 'known': redefining self-awareness through an understanding of self-narration processes in educational transitions. British Educational Research Journal, 35(2), 289-303. 